\title{
戰後當教室にて經驗せる尿石症の臨床的觀察
}

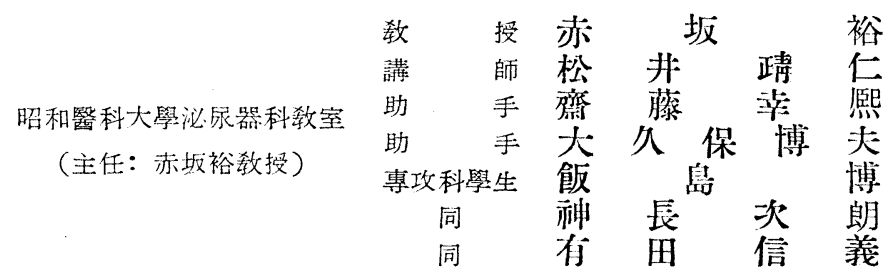

\section{CLINICAL SURVEY OF POST-WAR UROLITHIASIS IN UROLOGY DEPARTMENT OF SHOWA MEDICAL COLLEGE}

\author{
Hiroshi Akasaka, Shinji Matsui, Yukihiro Saito, \\ Hiroo Okubo, Hiroshi Iijima, Jiro Kaminaga \\ and Nobuyoshi Arita \\ From the Urology Department, Showa Medical College \\ (Director: Prof. H. Akasaka) \\ （本論交の要旨は第43回日本泌尿器科學會總會に於て發表した）
}

1. A total of 112 cases (2.69\%) of calculus of the urinary tract were experienced in the author's clinic during the period from August, 1945 to November, 1954. The cases consisted of 28 cases of renal calculus, 49 cases of ureteral calculus, 25 cases of vesical calculus, 8 cases of urethral calculus and 2 cases of prostatic calculus.

2. Since 1948, a clear increase in the incidence of the calculus was recognized, and an inc. rease in the cases of ureteral calculus was particularly observed. As to the cases of ureteral calculus, it was found that cases of abdominal ureteral calculus occupied $44.4 \%$ of the total and $47.3 \%$ were occupied by the cases of pelvic ureteral calculus, showing a tendency of gradual increase in the former.

3. When observed according to the age of the cases, the number of cases betwean the ages 21-29 exceeded the other age groups demonstrating 33.4\%. Cases among males were 6 times as many as that among females. Among the cases of upper urateral calculus, clearly higher incidence was obserued on the left side than on the right.

4. Spontaneous disciarge of the calculus in the cases of renal and ureteral calculus were recognized in a fairly high percentage.

5. Recurrences were recorded in 9 out of 19 cases among those directly examined by the authors and in 6 out of 43 cases investigated by questionnaires. Many recurrences were recsrded after lithotomy in the cases of renal culculus or pyelolithiasis. Most of the recurrences were recorded within 2 years from the operation. Furthermore, the size of the calculus at the time when they were first discovered was fairly large, consequently, the time lag betwean their formation and the operation was presumed to be long. In view of the above, the aut. hors concluded that due considerations should be given to the pathological changes in the locality of the calculus for the prevention of recurrence.

\section{緒 言}

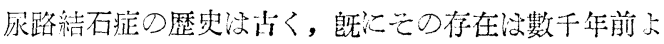
り知られるこころである, 而してその統計的並びに硻床
的觀察も數多くされているところであり, 又成因或治治 療法行關与る研究登表は枚擧にいし宗もない程でるる。 然しながら尚成因について定説定得るに至らず, 治潦 
法も亦既に出來上つた結石に對するものに過ざず, 完全 なる豫防或は再發防止等は未だ不可能の狀態で衣然とし て泌尿器科學に抢ける大きな課題である.時恰も第43包 日本泌尿器科學會總會に尿石症の臨床と賽驗が宿題報告 そして探りあげられたに際し, 我々も昭和20年 8 月より 29年11月までに教室に經驗した結石症患者について臨床 的觀察を行つてみた. 特に新たに附け加える程の事實は ないが，その結果老取りまとめて報告する次第である。

\section{尿路結石症の發生頻度}

第 1 表は外來患者數と結石患者の割合であり，4154名 中 112 名で $2.69 \%$ あるる.とれを昭和 30 年 4 月第 43 回日本 泌尿器科學會に打引る京都大學稻田務敎授の宿題報告の 結果と參照するに, 全國的には泌尿器科患者總數 452772 に鞉して尿路結石症患者數 17396であり $3.84 \%$ に相當し 我从の值は稍了低い數储走主。一般化尿路結石症の發 缃頻度以高橋氏 (1942) の述べる如く北方に薄く南方に 篦いとされ，東京地方はその中間に屬するとされてお る.稲田氏も同様順位に多少の變動はあるが北方に少く 献方多く，四國 (7.54\%) 中國 (6.01\%) 九州 $(4.85$ $\%)$ 近畿 $(4.69 \%)$ 中部 $(3.68 \%)$ 關東 $(2.99 \%)$ 東北 $(2.98 \%)$ 北海道 $(2.01 \%)$ の順となり, 關東地方は泌 尿器科患者數 135655 亿對乙結石患者數 4051 即5 $2.99 \%$ 亿 て我々の值と近似を示す。

\section{尿路結石の部位的分布}

第 2 表は上部及び下部尿路結石の年代的變遷であつて 明ら加結石波を㢹めることが出來る. 第 3 表快上部尿 路結石だけについてみたものであり, 腎結石は昭和 24 年 飞沶いて最高を示し尿管結石上り高位を示すが其後漸次 減少する傾向を示主に反し，尿管結石访次第に增加して
いることをみることが出來る．尚上部尿路結石定と下部 尿路結石症との差が最も䓕しい地方汴關東地方であり, 最も少小地方は東北地方である. 稻田氏は之注東北地方 にほ農業に從事する者が多く, 關東地方は俸給生活者 が多い烝, 農村と都會との食䬣の差, 生活狀態の差等 が恐らくその原因ではない考えられると述べてい る. そもそも歐州各地に捻いて注上部尿路結石症が増加 し，然も下部尿路結石症が決して増加しない現象は 1920 年頃より起り, Bibus 始め多數の學者により確認せら れててれを結石波と稱している. 本邦に拧いては既高 橋，楠氏等が東京地方においては1935年より結石波と考 えられる現象が現われたと報告し, 後藤氏は1936年より 1941年にかけて京都地方に打汀る結石波の存在を認め, 高安氏等が東京地方に抬いて1948年より結石波の存在省 報告している．全國的呚ても1937年より1944年にかけ て結石波を認め，戰後1947年より再び始つた結石波は最

第 2 表 上部, 下部尿路結石の年代的變遷

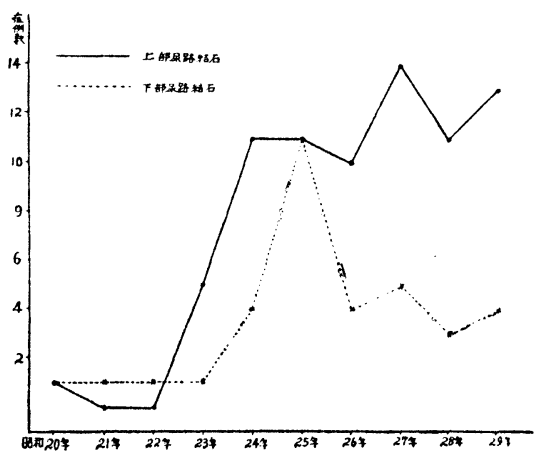

第 1 表 年 度 別 頻 度

\begin{tabular}{|c|c|c|c|c|c|c|c|c|c|c|c|c|c|c|c|c|c|}
\hline & 外 & & 者 數 & $\begin{array}{l}\text { 結石 } \\
\text { 患者數 }\end{array}$ & 百分率 & 腎 & 石 & 尿管 & & 膀 & & 尿i & & $\begin{array}{l}\text { 前 } \\
\text { 腺 }\end{array}$ & 立 & 結不 & \\
\hline 昭和 & 總 數 & $\hat{\delta}$ & q & $\hat{o}+q$ & $\hat{o}+0$ & $\hat{o}$ & o & $\hat{\delta}$ & 우 & $\hat{o}$ & 9 & $\hat{\delta}$ & 우 & $\hat{o}$ & ㅇ & $\hat{\delta}$ & 웅 \\
\hline 20 & 128 & 105 & 23 & 2 & 1.63 & 0 & 1 & 0 & 0 & 1 & 0 & 0 & 0 & 0 & & 1 & 1 \\
\hline 21 & 171 & 150 & 21 & 1 & 0.58 & 0 & 0 & 0 & 0 & 1 & 0 & 0 & 0 & 0 & & 1 & 0 \\
\hline 22 & 221 & 171 & 50 & 1 & 0.45 & 0 & 0 & 0 & 0 & 1 & 0 & 0 & 0 & 0 & & 1 & 0 \\
\hline 23 & 267 & 192 & 75 & 6 & 2.25 & 2 & 0 & 3 & 0 & 1 & 0 & 0 & 0 & 0 & & 6 & 0 \\
\hline 24 & 531 & 409 & 122 & 15 & 2.82 & 7 & 0 & 4 & 0 & 4 & 0 & 0 & 0 & 0 & & 15 & 0 \\
\hline 25 & 599 & 404 & 195 & 23 & 3.84 & 4 & 2 & 5 & 1 & 4 & 2 & 3 & 1 & 1 & & 17 & 6 \\
\hline 26 & 550 & 372 & 178 & 14 & 2.54 & 4 & 0 & 5 & 1 & 2 & 0 & 2 & 0 & 0 & & 13 & 1 \\
\hline 27 & 591 & 410 & 181 & 19 & 3.21 & 3 & 0 & 9 & 2 & 2 & 0 & 2 & 0 & 1 & & 17 & 2 \\
\hline 28 & 572 & 411 & 161 & 14 & 2.45 & 1 & 0 & 8 & 2 & 3 & 0 & 0 & 0 & 0 & & 12 & 2 \\
\hline 29 & 524 & 354 & 170 & 17 & 3.24 & 4 & 0 & 6 & 3 & 3 & 1 & 0 & 0 & 0 & & 13 & 4 \\
\hline 計 & 4154 & 2978 & 1176 & 112 & 2.69 & 25 & 3 & 40 & 9 & 22 & 3 & 7 & 1 & 2 & & 96 & 16 \\
\hline
\end{tabular}


近に抬いて大結石波にまで發展しているととが報告され ている・結石波の原因については診斷法の進歩も 1 つの 裂因であり, Mosqueria Lomas (1947) は近代生活侣 おける不斷の心身の緊張及び興奮による自律神經系の變 調が結石の發生を促進するとと發表し, 戰時及び戰後 における精神的及び肉體的の緊張及び興穓が大結石波の 一原因とも考えられるが, 唯之れだけでは解決されない 點もあり，今後に課された問題であると思われる。

第 3 表 上部尿路結石の年代的變遷

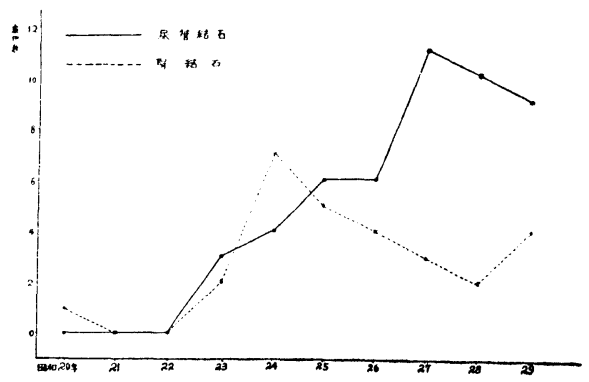

年龄的關係

第 4 表は結石患者の年路合曲線であり，主なる分布は20 荿代37例 ( $33.04 \%), 30$ 歳代 20 例 ( $17.86 \%), 40$ 歳代 21 例 ( $18.75 \%)$, 計78例 ( $69.64 \%)$ であり，青壯年層に 大部分を占められている．他の報告学曑照するに同様20 嵅代が最も多く，20嵅代及び30歳代に結石症が多いの泣 主として上部尿路結石症の激增にょるものであり，20歳 以下及び60歳以上に执いては上部尿路結石症の比率が低 い蘦とされている。

第 4 表 上部，下部尿路結石の年齝曲緗

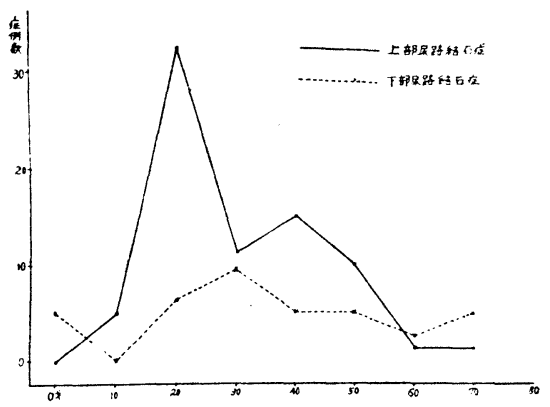

性的關係

第 5 表核男女別部位別の表である. 大體男子が女子の 6 倍となり, 稻田氏の本邦例の 5.6:1 と泟ぶ同值を示
すが，太田氏（16.68：1）高安氏等 $(7.61: 1)$ の發 表より低く〉なつている，年齡的にみると男子は20歳代 に打いて急激の增加を示しているが，女子に於ては著明 な増減を見られない。灭性別之結石部位との關係を及 るに, 男女の解剖學的差異のため膀胱及び尿道結石に打 いては男子は約 7 倍と算出するのは當然であるが，解剖 學的關係を同じくする上部尿路結石に执いても一般江男 子に多いものであるが, 特に腎結石に损いて約 8 倍を示 しているの浪女子例が少い爲であろう.

第 5 表 性別的關係

\begin{tabular}{|c|c|c|c|c|c|c|}
\hline 種類 & 總數 & $\hat{\delta}$ & 우 & $\delta:$ \& & $\begin{array}{c}\text { 高安, 齋 } \\
\text { 藤, 岸本 } \\
\hat{\delta}: \text { o }\end{array}$ & 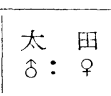 \\
\hline 亚結 石 & 28 & 25 & 3 & $8.3: 1$ & $3.5: 1$ & $3.59: 1$ \\
\hline 尿管結石 & 49 & 40 & 9 & $4.4: 1$ & $15.6: 1$ & $5: 1$ \\
\hline 膀脱結石 & 25 & 22 & 3 & $7.3: 1$ & $7.8: 1$ & $12.4: 1$ \\
\hline 尿道結石 & 8 & 7 & 1 & $7: 1$ & $25: 1$ & $74: 0$ \\
\hline 前立腺結石 & 2 & 2 & 0 & $2: 0$ & & \\
\hline 計 & 112 & 96 & 16 & $6: 1$ & $7.61: 1$ & $16.68: 1$ \\
\hline
\end{tabular}

\section{尿路結石の位置的分布}

第 6 表はンントダン所見の明瞭な尿管結石 36 例につい てその分布態定調查したのである.腹部16例 (44.4\%)， 骨盤骨部 3 例 ( $8.3 \%)$, 骨盤热部17例 (47.3\%)でとれ を戰前の高橋，楠，戸澤三氏（1928～1938）による腹部 尿管結石 32 例 $(24.6 \%)$ ，管盤胿部尿管絬石 97 例（74.6

第 6 表 尿管結石の位置的分布

\begin{tabular}{|c|c|c|c|c|c|c|c|}
\hline & & & 36例 & $\begin{array}{l}\text { 高安, 砂 } \\
\text { 岸本 }\end{array}$ & 81例 & 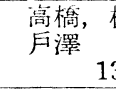 & \\
\hline \multirow{4}{*}{ 腹 } & $\mathrm{L}_{2-3}$ & \multirow{6}{*}{$\begin{array}{c}16 \\
(44.4 \%)\end{array}$} & 4 & \multirow{6}{*}{$\begin{array}{c}25 \\
(30.9 \%)\end{array}$} & 6 & \multirow{6}{*}{$\begin{array}{c}32 \\
(24.6 \%)\end{array}$} & 3 \\
\hline & $\mathrm{L}_{3}$ & & 3 & & 5 & & 8 \\
\hline & $\mathrm{L}_{3-4}$ & & 3 & & 5 & & 3 \\
\hline & $\mathrm{L}_{4}$ & & 4 & & 5 & & 14 \\
\hline \multirow[t]{2}{*}{ 部 } & $\overline{L_{4-5}}$ & & 1 & & 2 & & $\underline{3}$ \\
\hline & $\mathrm{L}_{5}$ & & 1 & & 2 & & 1 \\
\hline 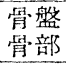 & & $(8.3 \%)$ & 3 & $(3.7 \%)$ & 3 & $(0.8 \%)$ & 1 \\
\hline \multirow{2}{*}{$\begin{array}{l}\text { 䉰·盤 } \\
\text { 腔部 }\end{array}$} & 膀胱外 & \multirow{2}{*}{$\begin{array}{c}17 \\
(47.3 \%)\end{array}$} & \multirow{2}{*}{$\begin{array}{c}10 \\
7\end{array}$} & 53 & \multirow{2}{*}{$\begin{array}{r}31 \\
\cdot 22\end{array}$} & \multirow[t]{2}{*}{97} & 61 \\
\hline & $\begin{array}{l}\text { 膀胱 } \\
\text { 壁內 }\end{array}$ & & & $(65.4 \%)$ & & & 36 \\
\hline
\end{tabular}

\%), 戰後の高安, 齋藤, 岸本三氏 (1945 1949) による 腹部尿管結石 25 例 (30.9\%), 骨盤腔部尿管結石53例(65.4 \%) に比較するに，漸次尿管結石がや〉上部に於て即ち 腹部尿管に於て發見される比率が多くなつているように 
思われる・とれは結石症の疑いのある患者が比較的早く 泌尿器科醫を訪犯て精查を受け, 確賽に䛦断される時期 が早くなつて來たことを意味するのではないかと考えら 礼る。

第 7 表は尿管結石の位置及び大きさの關係で大部分が $1.0 \mathrm{~cm}$ 以下の小結石で $71.33 \%$ 示している.

第 8 表は上部尿路結石の左右別であり，腎結石では左 15例, 右 8 例, 爾側 5 例, 尿管結石では左 30 例, 右 19 例 兩側 0 で共に左側に多く見られる。

\section{初發症狀並びに主訴による分類}

第 9 表は初發症状による 分類である.117例中疝痛 39 例 ( $33.33 \%)$ ，血尿25例 ( $21.37 \%)$ ，尿意頻數13例

( $11.11 \%)$ で主たるものである.上部尿路結石以疝痛, 血尿が多く, 下部尿路結石症では血尿, 排尿障豐が多い こと流知の通りでる.

第10表は初診時の主訴である.腎結石28例中疝痛 9 例, 血尿 9 例, 腎部の鈍痛 5 例, 計 23 例 ( $82.14 \%)$ で是等が
主訴の大部分を示している。尚排尿時疼痛, 尿意頻數定 訴えたものは膀胱炎の合併有していたものである。尿 管結石は 49 例中疝痛 20 例, 鈍痛 9 例で疼痛より及れ认゙ 29 例で 過半數を示し，乙れに血尿11例を加えれば計 40 例 （81.63\%）で主訴の大部分を示す。膀胱結石氺排尿时 疼痛 5 例, 疝痛, 血尿共比 4 例, 尿溷濁, 尿意頻數, 尿 閉及び排尿終末時疼痛共汇 3 例で，乙れらは膀胱炎の合 併化よる訴えが當然含まれているわけである，尿道結石 前立腺結石で斿特に記載すべきとといないが，上部尿路 のものでは疝痛及び血尿と共比鈍痛定訴えるものが多心 ことがや>特長と言つてよいであろう。

\section{結石の化學的分析}

第11表洁結石59例について，光の主要なる成分につい

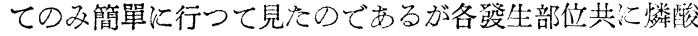
結石が最高で小棓 42 例 ( $71.19 \%)$ で大部分走示し，次 いで葆酸結石12例 ( $21.02 \%)$,炭酸結石 3 例及び尿酸結 石 2 例となつている.

第 7 表 㞘管結石の位置及び大さの關係

\begin{tabular}{|c|c|c|c|c|c|c|c|c|c|c|c|}
\hline \multirow{2}{*}{\multicolumn{2}{|c|}{ 大 部 }} & \multicolumn{3}{|c|}{ 腹 } & \multicolumn{3}{|c|}{ 部 } & \multirow{2}{*}{$\begin{array}{ll}\text { 骨 盤 } \\
\text { 骨 部 }\end{array}$} & \multicolumn{2}{|c|}{ 骨”盤 腔 部 } & \\
\hline & & $\mathrm{L}_{2-3}$ & $\mathrm{~L}_{3}$ & $\mathrm{~L}_{3-4}$ & $\mathrm{~L}_{4}$ & $\mathrm{~L}_{4-5}$ & $I_{5}$ & & 膀脱外 & $\begin{array}{ll}\text { 膀 } & \text { 胱 } \\
\text { 壁 }\end{array}$ & \\
\hline 大 & $2 \mathrm{~cm}$ 以上 & & & & & & & & & & 0 \\
\hline 中 & $1 \mathrm{~cm}$ 以上 & & 1 & & 2 & & 1 & & 1 & 1 & 6 \\
\hline 小 & $1 \mathrm{~cm}$ 以下 & 4 & 2 & 3 & 2 & 1 & 0 & 3 & 9 & 6 & 30 \\
\hline & $\%$ & & & & & & & $\begin{array}{c}3 \\
8.3 \%\end{array}$ & & & $\begin{array}{c}36 \\
100 \%\end{array}$ \\
\hline
\end{tabular}

焦點 $65 \mathrm{~cm}$ のレ線像にて直徑 $\left\{\begin{array}{l}2 \mathrm{~cm} \text { 以上 大 } \\ 1 \mathrm{~cm} \text { 以上卡 } \\ 1 \mathrm{~cm} \text { 小 }\end{array}\right.$

第 8 表 上部尿路結石の左右差

\begin{tabular}{|c|c|c|c|c|c|c|c|c|c|c|}
\hline & \multicolumn{4}{|c|}{ 腎 結 石 } & \multicolumn{4}{|c|}{ 良 管 結 石 } & \multirow{2}{*}{ 計 } & \multirow{2}{*}{ 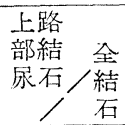 } \\
\hline 度別 & 右 & 兩 & 左 & 計 & 右 & 兩 & 左 & 計 & & \\
\hline 昭和20年 & 1 & 0 & 0 & 0 & 0 & 0 & 0 & 0 & 1 & $1 / 2$ \\
\hline 21 & 0 & 0 & 0 & 0 & 0 & 0 & 0 & 0 & 0 & $0 / 1$ \\
\hline 22 & 0 & 0 & 0 & 0 & 0 & 0 & 0 & 0 & 0 & $0 / 1$ \\
\hline 23 & 1 & 1 & 0 & 2 & 2 & 0 & 1 & 3 & 5 & $5 / 6$ \\
\hline 24 & 1 & 2 & 3 & 6 & 2 & 0 & 2 & 4 & 10 & $10 / 13$ \\
\hline 25 & 1 & 1 & 5 & 7 & 2 & 0 & 4 & 6 & 13 & $13 / 23$ \\
\hline 25 & 1 & 0 & 3 & 4 & 5 & 0 & 1 & 6 & 10 & $10 / 19$ \\
\hline 27 & 2 & 0 & 1 & 3 & 0 & 0 & 12 & 12 & 15 & $15 / 19$ \\
\hline 28 & 0 & 0 & 1 & 1 & 4 & 0 & 5 & 9 & 10 & $10 / 15$ \\
\hline 29 & 1 & 1 & 2 & 4 & 4 & 0 & 5 & 9 & 13 & $13 / 17$ \\
\hline 計 & 8 & 5 & 15 & 27 & 19 & 0 & 30 & 49 & 77 & \\
\hline
\end{tabular}


第 9 表 初發症狀による分類

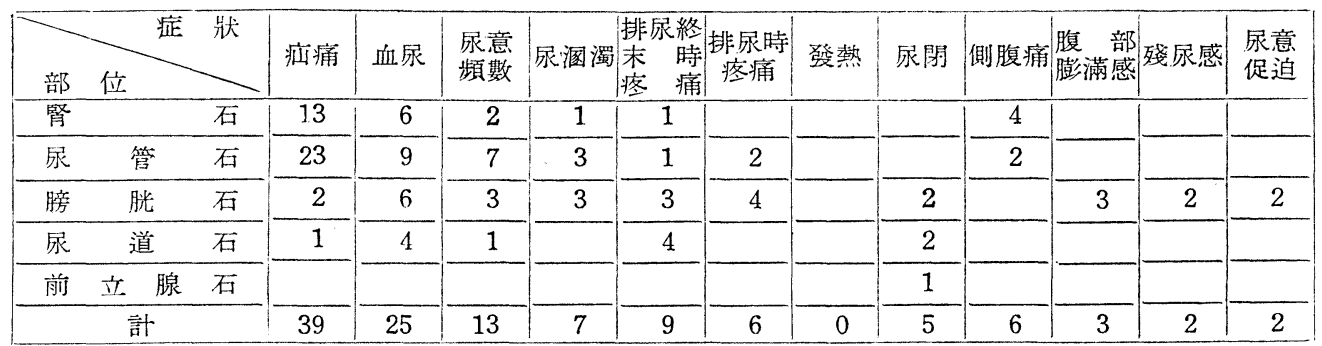

第10表 主訴別による分類

\begin{tabular}{|c|c|c|c|c|c|c|c|c|c|c|c|c|c|c|}
\hline 症 狀 & 疝痛 & 血尿 & 鈍痛 & $\begin{array}{c}\text { 排层時 } \\
\text { 疼痛 }\end{array}$ & 尿泪濁 & $\begin{array}{l}\text { 尿意 } \\
\text { 頻數 }\end{array}$ & 尿閉 & $\begin{array}{l}\text { 排 永 } \\
\text { 終末痛 }\end{array}$ & 腹 部 & $\begin{array}{l}\text { 尿線 } \\
\text { 中絕 }\end{array}$ & 殘尿感 & $\begin{array}{l}\text { 䐂線 } \\
\text { 狹少 }\end{array}$ & $\begin{array}{l}\text { 尿意 } \\
\text { 促迫 }\end{array}$ & $\begin{array}{l}\text { 尿線 } \\
\text { 斷裂 }\end{array}$ \\
\hline 腎石 & 9 & 9 & 5 & 1 & 1 & 2 & & & 1 & & . & & & \\
\hline 尿 管 石 & 20 & 11 & 9 & 2 & 4 & 1 & & 1 & 1 & & & & & \\
\hline 膀 胱 石 & 4 & 4 & 1 & 5 & 3 & 3 & 3 & 3 & & 1 & 1 & & 1 & 1 \\
\hline 尿 道 石 & 1 & 4 & & 2 & & 1 & 2 & & & & & 1 & & \\
\hline 前立腺石 & & & & & & & 1 & & & & & & & \\
\hline 計 & 34 & 28 & 15 & 10 & 8 & 7 & 6 & 4 & 2 & 1 & 1 & 1 & 1 & 1 \\
\hline
\end{tabular}

第11表 結石の化學的分析

\begin{tabular}{|c|c|c|c|c|c|}
\hline 主要成分 & $\begin{array}{l}\text { 燐酸 } \\
\text { 結石 }\end{array}$ & $\begin{array}{l}\text { 蓚酸 } \\
\text { 結石 }\end{array}$ & $\begin{array}{l}\text { 炭酸 } \\
\text { 結石 }\end{array}$ & $\begin{array}{l}\text { 尿酸 } \\
\text { 結石 }\end{array}$ & 計 \\
\hline 腎 結 石 & 9 & 6 & 1 & 0 & 16 \\
\hline 尿管結石 & 19 & 1 & 1 & 1 & 22 \\
\hline 膀胱結石 & 8 & 4 & 1 & 1 & 14 \\
\hline 尿道結石 & 5 & 1 & 0 & 0 & 6 \\
\hline 前立腺結石 & 1 & 0 & 0 & 0 & 1 \\
\hline 計 & 42 & 12 & 3 & 2 & 59 \\
\hline
\end{tabular}

\section{治療别による分類}

第12表は患者 109例についての分類である. 自然排出 33例で第 1 位定示し, 特に尿管結石の自然排出がその内 24例で高率在示している. かくの如く自然排出特に尿管 結石の自然排出の高率なるとと以更に積極的に確實に自 然排出定促進し得る方法肎早く發見出爽るならば患者の
幸いこれに過ぎるものはないと思われる。

次いで尿管腎孟切石術 30 例, 異物鉗子による摘出術 18 例であり，これは膀胱結石15例の他尿管結石の尿管口儿 嵌入するもの3 例字含むものである. 尚非治療11例依檢 查の及を行つて後日來院せざる者及び檢查の及虽院に 依頼し來たるもの含んでいる。

\section{尿路結石治療後の遠隔成綪}

尿路結石患者 112 例の内アンケートによりて囦答是得 たもの43例, 直接来院の上检查字行つたもの19例につい ての再發例は第13表に示す如くであつて, アンケートに よるもの43例中 6 例, 直接檢查の上發見せるもの19例中 9 例である。これを部位別にみるこ, 䝳結石10例で间率 走し, 次いで尿管結石 2 例亡尿道絬石 1 例及び最初は 腎，疛管結石で再發來院時に尿道に結石学發見しかもの 2 例でむる。尚全例共に男子の奴で女子には再發例决認 めら礼なかな。

第 12 表治療別に上る分類

\begin{tabular}{|c|c|c|c|c|c|c|c|c|c|c|c|}
\hline 程 類 & $\begin{array}{l}\text { 宸 篢 } \\
\text { 督 } \\
\text { 切石術 }\end{array}$ & 碎在術 & $\begin{array}{l}\text { 高 位 } \\
\text { 切開術 }\end{array}$ & $\begin{array}{l}\text { 腎 } \\
\text { 出 }\end{array}$ & $\begin{array}{l}\text { 剔 } \\
\text { 術 }\end{array}$ & 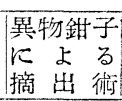 & $\begin{array}{l}\text { 泉 道 } \\
\text { 切開術 }\end{array}$ & $\begin{array}{l}\text { 自 然 } \\
\text { 排 出 }\end{array}$ & $\begin{array}{l}\text { 經辰道的 } \\
\text { 摘 出 術: }\end{array}$ & $\begin{array}{l}\text { 前立腺 } \\
\text { 結石 } \\
\text { 摘出術 }\end{array}$ & 非治療 \\
\hline 腎 結 石 & 14 & & & & 4 & & & 2 & & & 7 \\
\hline 莪 管 結 石 & 16 & & & & 1 & 3 & & 24 & & & 4 \\
\hline 膀 㧤 結 石 & & 1 & 3 & & & 15 & & 6 & & & \\
\hline 家 道 結 石 & & & & & & & 2 & 1 & 5 & & \\
\hline 前立腺結石 & & & & & & & & & & 1 & \\
\hline 計 & 30 & 1 & 3 & & 5 & 18 & 2 & 33 & 5 & 1 & 11 \\
\hline
\end{tabular}


第13表 部位別による再發例

\begin{tabular}{|c|c|c|c|}
\hline 部 位 & $\begin{array}{l}\text { 發 } \\
\text { 結不 } \\
\text { 總數 }\end{array}$ & 再發例／ & 再發例／ \\
\hline 腎 結 石 & $10 / 28$ & $10 / 25$ & $0 / 3$ \\
\hline 尿管結石 & $2 / 49$ & $2 / 40$ & $0 / 9$ \\
\hline 膀胱結石 & $0 / 25$ & $0 / 22$ & $0 / 3$ \\
\hline 尿道結石 & $3 / 8$ & $3 / 7$ & $0 / 1$ \\
\hline 前立腺結石 & $0 / 2$ & $0 / 2$ & $0 / 0$ \\
\hline 計 & $15 / 112$ & $15 / 96$ & $0 / 16$ \\
\hline
\end{tabular}

第14表は治療別にみた再發例であり, 腎, 腎盎切石術 を行つた後のもの5例で最も多く, 次は自然排出後に 2 〜 3 ケ月又は 6 ケ月毎に小豆大乃至米粒大の小結石の排 出安訴える者 3 例であり, 結石の性狀悢粼酸結石であつ た.

切石術後の再發は尿管結石の 1 例のみが術後13年にし て再發芫發見して扔り，他は全て 2 年以内である. 從つ て手術的結石除去後 2 年以特に再發防止の票に考慮乃至 處置が望ましいのではないて思われる. 又再發例は何 れも初包發見時の結石が比較的大きく, 從つて結石發生 より手術迄の期間が長く, 結石發生性局所病變が結石が 永く介在するととにより永續性となり, 再發も來たし易 くなつていたといつてよいのではないかと思われる.從 つて自然排出の可能性のないもの又は困難と考えられる ものでは可及的早く切石術を行つて結石安除去すること が，再發防止に役立つのではないかと考えられる.又腎 杯に結石の嵌頓している如きものにては單に結石を除去 するにとがまらず腎部分切除定行うことが再發防止の上 からは望ましいことである。

再發時の症狀としては一般に輕度のものが多いよう で，第15表に示す如くである.とれは壁固着性の結石が 多い䉆ではないかと思われる.從つて現在では未だ再發 防止の確實な方法はないのであるが, 結石症患者に於て は結石除去後自覺症狀を訴えることがなくとも，我及の 知れる範圍に於て再發防止の方法安講ずるここは肝要な ことである。
第15表 再苰時症狀

\begin{tabular}{|c|c|c|c|c|c|c|c|c|c|c|}
\hline $\mid \begin{array}{c}\text { 部 } \\
\text { 位 } \\
\text { 症 }\end{array}$ & $\begin{array}{l}\text { 疝 } \\
\text { 痛 }\end{array}$ & $\begin{array}{l}\text { 血 } \\
\text { 尿 }\end{array}$ & $\begin{array}{l}\text { 永頻 } \\
\text { 意數 }\end{array}$ & $\begin{array}{l}\text { 尿 } \\
\text { 淘 } \\
\text { 濁 }\end{array}$ & $\begin{array}{l}\text { 排疼 } \\
\text { 水 } \\
\text { 時痛 }\end{array}$ & $\begin{array}{l}\text { 發 } \\
\text { 熱 }\end{array}$ & $\begin{array}{l}\text { 尿 } \\
\text { 闒 }\end{array}$ & $\begin{array}{l}\text { 側鈍 } \\
\text { 腹 } \\
\text { 部痛 }\end{array}$ & $\begin{array}{l}\text { 排減 } \\
\text { 家 } \\
\text { 力退 }\end{array}$ & $\begin{array}{l}\text { 自排 } \\
\text { 然出 }\end{array}$ \\
\hline 腎結石 & 1 & 3 & 1 & & 1 & 1 & & 1 & & 1 \\
\hline $\begin{array}{l}\text { 尿管 } \\
\text { 結石 }\end{array}$ & 1 & & & & & & & 2 & & \\
\hline $\begin{array}{l}\text { 膀腃 } \\
\text { 結石 }\end{array}$ & & & & & & & & & & \\
\hline $\begin{array}{l}\text { 柡道 } \\
\text { 結石 }\end{array}$ & 1 & & & & & & & & 1 & \\
\hline $\begin{array}{l}\text { 前立腺 } \\
\text { 結石 }\end{array}$ & & & & & & & & & & \\
\hline 計 & 3 & 3 & 1 & 0 & 1 & 1 & 0 & 3 & 1 & 1 \\
\hline
\end{tabular}

結語

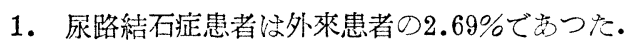

2. 戰後昭和 22 年より結石波を認わた。

3. 上部尿路結石症の増加は尿管結石の増加による。

4. 年齡的關係は20歳代 ( $33.04 \%)$ が他字倰駕して 多く, 幼年者, 高年者は極妙ない.

5. 男子は女子の6 倍字示す.

6. 腹部尿管結石が $44.4 \%$ あり, 霄盤腔部尿管結石 $47.3 \%$ あり, 前者が漸増の傾向定示す.

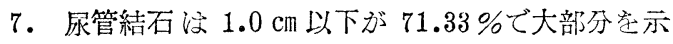
के.

8. 上部尿路結石に执いて左側が右側に比して明心に 頻度が高い。

9. 初發症狀は疝痛, 血尿, 尿意頻數が主なるもので ある・

10. 初診時主訴の主なるものは疝痛, 次いで血尿, 鈍 痛である。

11. 燐酸結石 ( $71.19 \%)$ 蓚酸結石 ( $21.02 \%)$ の他 炭酸結石 (5.08\%), 尿酸結石 (3.39\%).

12. 自然排出特に尿管結石の自然排出が比較的高率に みられた。

13. 再發例はアンケートによるもの43例中 6 例, 直接 檢查の上發見されたるもの19例中 9 例浔めた。

第14表 治療別による再發例

\begin{tabular}{|c|c|c|c|c|c|c|c|c|c|c|c|c|c|c|}
\hline 種 & & 類 & $\begin{array}{l}\text { 篎切 } \\
\text { 筒石 } \\
\text { 皿術 }\end{array}$ & $\begin{array}{r}\text { 尿切 } \\
\text { 石 } \\
\text { 管術 }\end{array}$ & $\begin{array}{l}\text { 腎 } \\
\text { 剔 } \\
\text { 出 } \\
\text { 術 }\end{array}$ & $\begin{array}{l}\text { 碎 } \\
\text { 石 } \\
\text { 術 }\end{array}$ & $\begin{array}{r}\text { 高切 } \\
\text { 開 } \\
\text { 位術 }\end{array}$ & $\mid \begin{array}{l}\text { 異に摘 } \\
\text { 物 よ出 } \\
\text { 銝 } \\
\text { 子る術 }\end{array}$ & $\begin{array}{l}\text { 自 } \\
\text { 然 } \\
\text { 排 } \\
\text { 出 }\end{array}$ & $\begin{array}{r}\text { 尿切 } \\
\text { 開 } \\
\text { 道術: }\end{array}$ & $\begin{array}{l}\text { 緢摘 } \\
\text { 瓜 } \\
\text { 道出 } \\
\text { 的術 }\end{array}$ & $\begin{array}{l}\text { 前石 } \\
\text { 辛摘 } \\
\text { 腺出 } \\
\text { 結術 }\end{array}$ & $\begin{array}{l}\text { 非 } \\
\text { 治 } \\
\text { 療 }\end{array}$ & 計 \\
\hline 總 & & 數 & 14 & 16 & 5 & 1 & 3 & 18 & 33 & 2 & 5 & 1 & 11 & 109 \\
\hline 死 & 亡 & 例 & 0 & 0 & 1 & 0 & 1 & 0 & 1 & 0 & 0 & 0 & 0 & 3 \\
\hline 再 & 發 & 例 & 5 & 1 & 0 & 0 & 0 & 2 & 3 & 0 & 1 & 0 & 0 & 12 \\
\hline
\end{tabular}


14. 霄，腎盂切石術後の再發例が多くみられた。

15. 切石術後の再發は手術時に比較的大きな結石に多 くみられ, 大部分が 2 ケ年以内であり, 再發防止のため の考慮乃至處置が望ましい.

\section{茄考文獻}

1) Bibus: Z. Urol., 33, 37, 1939.

2）後藤櫓, 新谷浩，八田榮造：皮紀要，49，286, 昭和 28 年.

3）稻时務他：泌尿器科紀要， 46, 7, 50, 昭和30
年。

4) 楠隆光: 脲路結石症, 䇴家叢書, 47, 昭和25年.

5 ) Mosqueria and Lomas: J. Urol., 57, 1142, 1947.

6）太田三郎：皮䖉と泌尿，16，5，昭和29年.

7 ) 高橋明, 楠隆光, 戶澤孝: 日泌尿會誌, $\mathbf{3 0}, 2$, 昭和16年。

8）高橋明, 楠隆光：日泌家會誌，32，6，581，昭 和17年.

9 ) 高安久雄, 齋藤豐一，岸本孝：日泌尿會誌, 41, 5,139 , 昭和 25 年. 